\title{
RESEARCH ON THE RUNOFF OF ARID DESERT GRASSLANDS UNDER CHANGING ENVIRONMENTS IN CHINA
}

\author{
HAO, W. G. ${ }^{1,2}-$ LI, H. P. ${ }^{1,2}-$ LIU, H. ${ }^{1,{ }^{*}}-$ WANG, L. X. ${ }^{2}-$ JIAO, R. ${ }^{2}-$ LIU, H. L. ${ }^{2}-$ SONG, Y. F. ${ }^{2}$ \\ CUI, L. P. ${ }^{2}$ \\ ${ }^{I}$ State Key Laboratory of Simulation and Regulation of Water Cycle in River Basin, China \\ Institute of Water Resources and Hydropower Research, Beijing 100044, China \\ ${ }^{2}$ Ministry of Water Resources of Pastoral Water Institute of Science, Hohhot 010020, China \\ (phone: +86-130-8712-1336) \\ *Corresponding author \\ e-mail:13087121336@163.com; phone: +86-130-8712-1336; fax: +86-047-1469-0603 \\ (Received 30 ${ }^{\text {th }}$ Aug 2019; accepted $12^{\text {th }}$ Feb 2020)
}

\begin{abstract}
Reasonable allocation of water resources in dryland pastures plays a decisive role in local ecological protection and economic development. Changes in the local climate and vegetation have a direct impact on the local runoff. With Darhan Muminggan Joint Banner (DM Banner) as the study area in China, we made use of the Soil and Water Assessment Tool (SWAT) hydrological model, calibrated and fitted the parameters into the model according to the local meteorological statistics and data on land utilization, soil texture and runoff. After fitting and calibration, we built a SWAT model for arid desert grasslands to simulate and forecast re-distribution of water resources in the study area under changes in the climate and vegetation. This study is expected to provide technical support for reasonable development and utilization of water resources in dryland pastures as well as ecological recovery in Inner Mongolia of China.

Keywords: water resources, SWAT model, hydrological response unit, scenario simulation, efficient utilization
\end{abstract}

\section{Introduction}

The hydrological process of surface runoff is a very complicated natural mechanism subject to impacts of multiple factors including the climate, geomorphological conditions and vegetation. This process follows varied working mechanisms under different dimensions of time and space, and the accompanying water dynamics and water circulation in the process is subject to changes by time, space and the conditions of the underlying surface. The hydrological process can be divided into three interconnected parts: the physical process, the chemical process and the ecological effect. The runoff yield and confluence are closely correlated with the hydrological process in dryland pastures (Wang et al., 2003, 2008; Zhang et al., 2003, 2005; Huang and Zhang, 2010).

To identify the mechanism of the hydrological cycle in the arid pastoral area under climate changes and intensive human activities in this region of China, this study used the SWAT model to simulate the runoff of the arid pastoral area in DM Banner in Inner Mongolia, China, and analyzed the changes in the runoff with changes in land utilization to provide a scientific basis for optimized management of land resources and water resources in this region. 


\section{Review of Literature}

The SWAT model is a distributed hydrological model developed by USDA Agricultural Research Center (USDA-ARS), which is a distributed hydrological model developed on the basis of CREAMS, EPIC, GLEAMS and other models. SWAT model can simulate the effects of land management activities on water volume and quality, sediment migration, pesticide and nutrient leaching in large and complex rivers (Hoang et al., 2017). Manoj and Friedrich (2016) applied SWAT model to conduct comparative evaluation on the simulation results of runoff and nutrient loads in Onkaparingacatchment basin of south Australia through single-station and multi-station calibration. Bannwarth et al. (2014) applied SWAT model to simulate the pesticide transport in Mae Sa basin in northern Chiang mai, Thailand. El-Khoury et al. (2015) used SWAT model to simulate the effects of future climate and land use changes on nitrogen and phosphorus content in Canadian river basins. On the basis of research achievements by international researchers, researchers in China have improved research methods and used new technologies in recent years, and they have made substantial progress in analysis, simulation and forecast of runoff generation and confluence. Many Chinese researchers have done research on changes of runoff in different regions via the SWAT model, such as studies on water basins in Loess Plateau, studies on the Black River basin by Lai et al. (2013), studies on the Wei River basin by Zhao et al. (2015), studies on the Jing River basin along the northern slope of Mount Tianshan in Xinjiang by Meng et al. (2014), and studies on the Kuye River basin by Cheng et al. (2009). Besides, Duan et al. (2014) and Guo et al. (2014) analyzed whether the SWAT model was applicable to research on the Huang-Huai-Hai region. Li et al. (2013) and Yuan et al. (2015) have studied the influence of land utilization and climate changes on the runoff of the Taihu basin and the Liuxi River basin, respectively, in 2013 and 2015. Li et al. (2014) analyzed the characteristics of changes in the land surface albedo on Loess Plateau. Chen et al. (2014) made forecasts on the runoff of the purple-soil slope land in basins and hills in southeast China. Wei et al. (2014) made sensitivity analysis of the SWAT model to landscape changes with the Old Guan River basin in Danjiangkou as the study case in 2014. Yu et al. (2013) improved the computing of the snowmelt module in SWAT with Yingluo Gorge in Shaanxi as the study case.

Studies mentioned above focused on regions including the Loess Plateau, mountainous areas in southwest China and hills in Sichuan and Shanxi; however, there are few studies made on arid grasslands in Inner Mongolia that are subject to semi-arid and arid continental climates in the temperate climate zone. Currently, few studies have been made on correlations between the hydrological process of surface runoff in in China's arid pastoral area and the local climate and ecology, so it is difficult to summarize the hydrological mechanism of this special region according to existing studies.

\section{Materials and Methods}

\section{Study Area}

Located in the north of Baotou City, Inner Mongolia Autonomous Region, China, Darhan Muminggan Joint Banner adjoins Mongolia on the north, the Wulate Middle Banner of Bayannur City on the west, Wuchuan County of Hohhot and Guyang County of Baotou on the south, and the Siziwang Banner of Ulanqab on the east. The 
geographic coordinates are between $41^{\circ} 16^{\prime} \mathrm{N}$ and $42^{\circ} 45^{\prime} \mathrm{N}$, between $109^{\circ} 15^{\prime} \mathrm{E}$ and $111^{\circ} 25^{\prime} \mathrm{E}$. Under the administration of this banner are Bayinhua Town, Mandula Town, Wuke Town, Shibao Town, Bailingmiao Town, Xilamuren Town, Mingan Town and Darhan Sumu, covering an area of $18177 \mathrm{~km}^{2}$. Subject to the temperate continental climate, the DM Banner has cold winters, dry springs with strong sandstorms and hot summers. The average annual temperature in this region is $4.34^{\circ} \mathrm{C}$, the highest annual temperature reaches $38^{\circ} \mathrm{C}$ and the lowest reaches $-39.4^{\circ} \mathrm{C}$. The maximum precipitation is $425.2 \mathrm{~mm}$, the minimum precipitation is $165.3 \mathrm{~mm}$, and the average annual precipitation is $253.45 \mathrm{~mm}$. The average amount of surface water evaporation is $2480.57 \mathrm{~mm}$ and the frost-free season lasts 90 to 120 days long. The Banner is located on the north of Mountain Daqing and the central area of the Inner Mongolian Plateau. With the southern region higher than the northern region, the study area has low mountains in the south, mild hills in the north and a flat and open plateau in the center, with an average altitude of $1376 \mathrm{~m}$. With the highest altitude of $1846 \mathrm{~m}$ at Habtegegisu Ovoo, mountains in the study area is about $1300 \mathrm{~m}$ high, with a relative elevation of $30 \mathrm{~m}$ to $100 \mathrm{~m}$. The Tengenor Lake marks the lowest point of the study area, with an altitude of $1058 \mathrm{~m}$. Due to horizontal and vertical soil zones, the soil structure of the DM Banner has salient zonal features; meanwhile, because of differences in the landform and water resources, part of the soil in the study area shows intrazonal features.

The natural vegetation in DM Banner varies as the landform, soil, and hydrothermal conditions differ, forming three vegetation zones - typical arid grassland vegetation zone, desert grassland zone and steppe desert zone, from south to north, with vegetation of steppe deserts as the major type of vegetation. The typical arid grassland is mainly in the southern part of the Banner, accounting for $33 \%$ of the total area of grasslands there, the rate of grass coverage reaches $28 \%$. The desert grassland is in the central area of the Banner, covering 27\% of the area of the grassland in the Banner, the rate of grassland coverage is between $22 \%$ to $23 \%$. The steppe desert is located in the north of the Banner, covering 35\% of the area of the grasslands in the Banner, the vegetation is sparse and the rate of grassland coverage is between $15 \%$ and $22 \%$.

\section{Database Building and Data Analysis}

Through the SWAT2009 model the paper builts a model for the basin of the arid pastoral area in DM Banner. The data required to build the SWAT model are shown in Table 1. Of all the parameters used by the model, rainfall uses the series daily precipitation provided by Bailingmiao Hydrological Station and Meteorological Station (not a site) from 1975 to 2015. And meteorological data includes mean daily maximum temperature for 12 months, mean daily minimum temperature for 12 months, daily deviation of monthly maximum temperature, daily deviation of monthly minimum temperature, monthly mean precipitation, monthly precipitation deviation, monthly day precipitation skewness coefficient, two precipitation probabilities of wet and dry transition, monthly mean precipitation days, most half hour precipitation, monthly mean net solar radiation, monthly average dew point temperature and monthly mean wind speed. All the parameters of the Bailingmiao Meteorological and Hydrological stations for 12 months are calculated by programming according to the daily data and written into the meteorological database according to the input format of the model. 
Table 1. Basic Information and Source of Modelling Data

\begin{tabular}{|c|c|c|c|c|}
\hline Data & Resolution & Length of time & Format & Source \\
\hline DEM & $30 \mathrm{~m} \times 30 \mathrm{~m}$ & & GRID & $\begin{array}{c}\text { National Imagery and Mapping Agency } \\
\text { (NIMA) \& National Aeronautics and Space } \\
\text { Administration (NASA) }\end{array}$ \\
\hline $\begin{array}{l}\text { Vegetation } \\
\text { map }\end{array}$ & $1: 1,000,000$ & & GRID & Institute of Grassland Research of CAAS \\
\hline Soil type & $1: 1,000,000$ & & GRID & Institute of Soil Science, CAS \\
\hline $\begin{array}{c}\text { Meteorological } \\
\text { data }\end{array}$ & Daily scale & $1975-2015$ & $\mathrm{DBF}$ & $\begin{array}{l}\text { Bailingmiao Meteorological Station } \\
\text { Daily precipitation, Daily maximum and } \\
\text { minimum temperature, Mean daily } \\
\text { temperature, Daily humidity, Daily wind } \\
\text { speed, Daily solar radiation, etc }\end{array}$ \\
\hline $\begin{array}{l}\text { Hydrological } \\
\text { data }\end{array}$ & Daily scale & $1975-2015$ & XLSX & $\begin{array}{c}\text { Bailingmiao Hydrological Station } \\
\text { Monthly average runoff, Daily precipitation, } \\
\text { Daily mean temperature, etc }\end{array}$ \\
\hline
\end{tabular}

\section{DEM-based Hydrological Data Extraction}

The basin map is produced based on the surface runoff model and according to the flow routes identified by the concept of hydrological overland flow. This method determines the direction of water flow according to the largest slope between a given grid cell in the DEM (Figure 1) and its eight adjacent cells, calculates the area of upstream catchment area of each cell, demarcates a drainage basin according to the threshold of a catchment area and extracts the hydrological features of the study area, as shown in Figure 2.

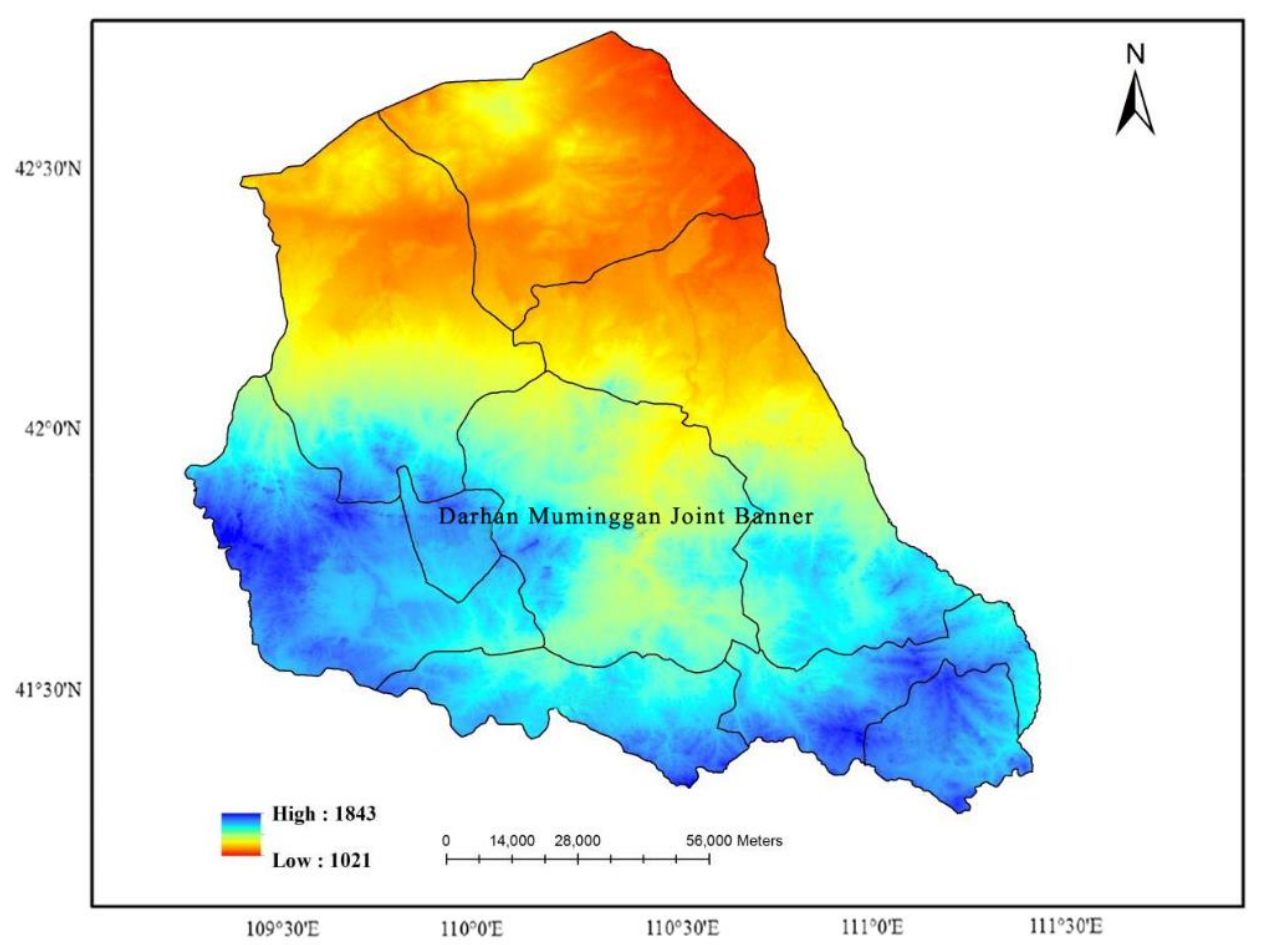

Figure 1. Digital Elevation Model of DM Banner 


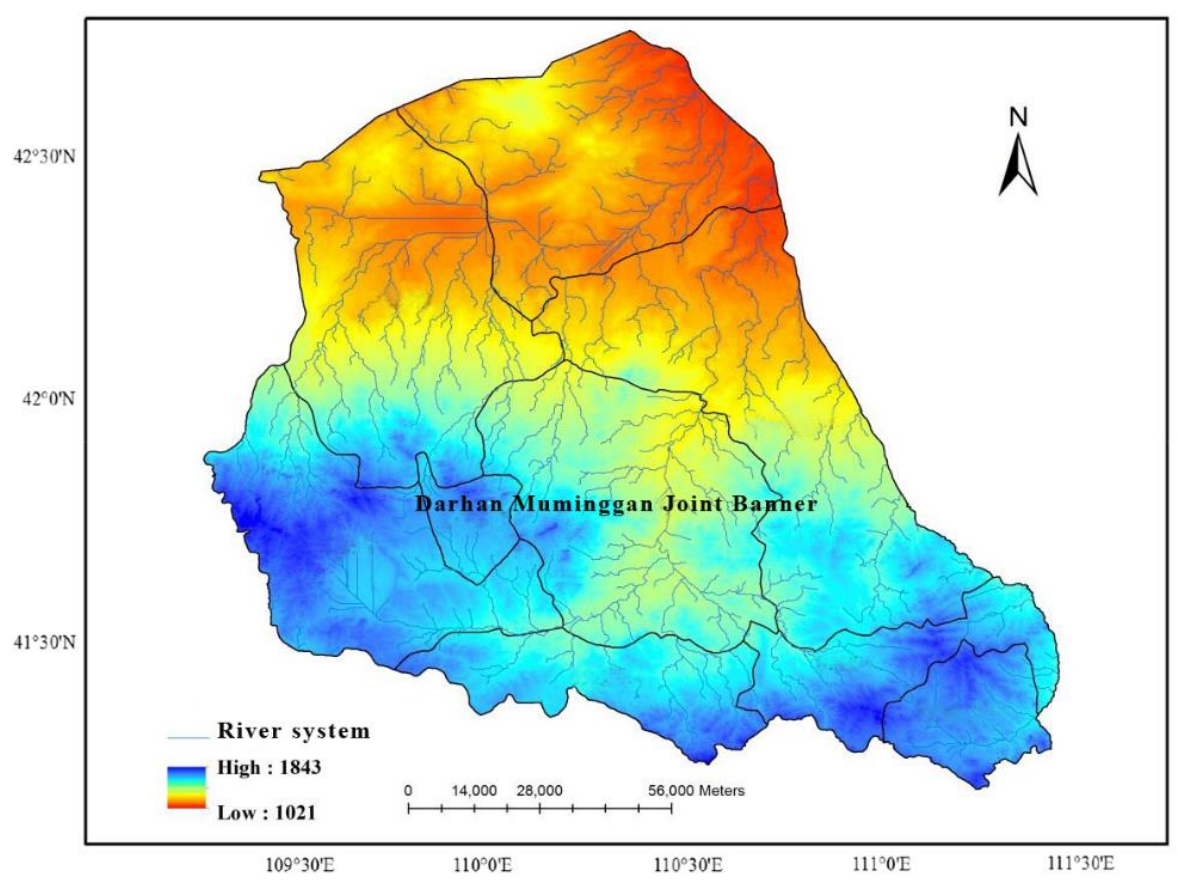

Figure 2. Natural Drainage System of DM Banner

\section{Soil Database}

The soil database uses the traditional "soil genetic classification" system and the basic charting unit is the subgroup level. There are 12 types of soil in the study area, including Calcic Gleysols (GLk), Cambic Arenosols (ARb), Calcaric Arenosols (ARc), Luvic Calcisols (CLl), Calcaric Fluvisols (FLc), Salic Fluvisols (FLs), Haplic Kastanozems (KSh), Calcic Kastanozems (KSk), Calcaric Phaeozems (PHc), Gleyic Phaeozems (PHg), Calcic Planosols (PLk) and Water Regime (WR), as shown in Figure 3.

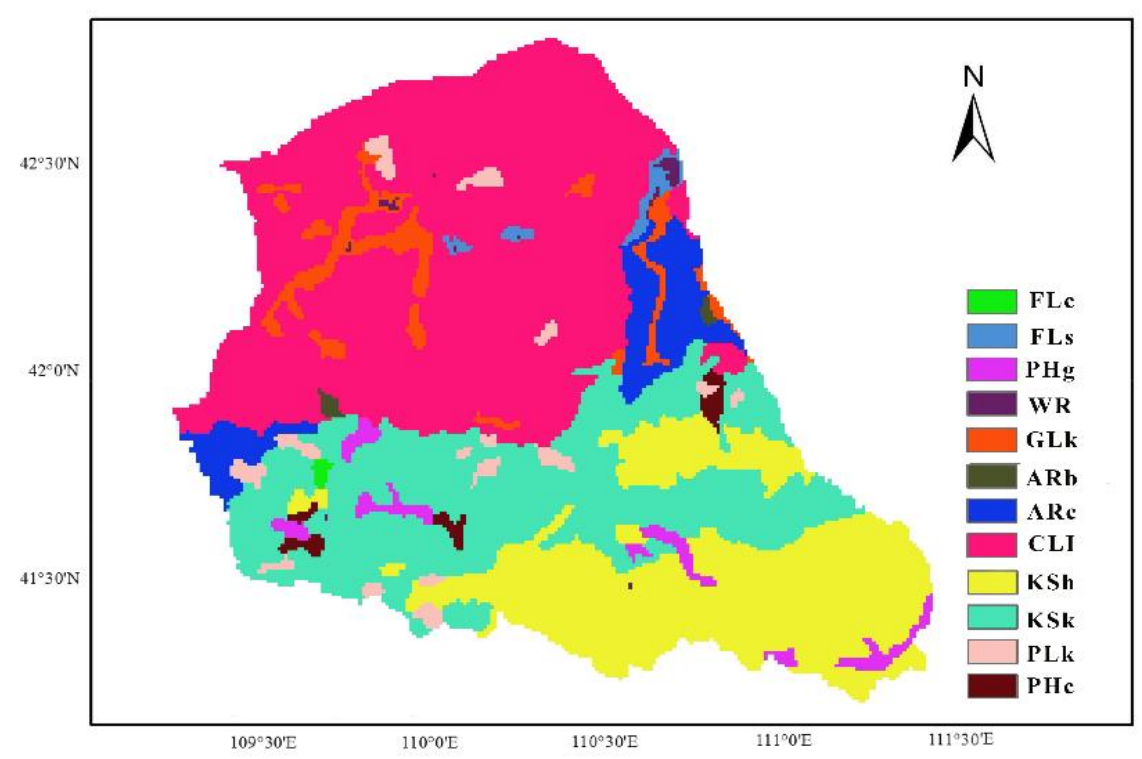

Figure 3. Types of Soil in DM Banner 
The soil database needs to input physical and chemical parameters of various types of soil, mainly including soil name, soil stratification number, soil hydrology grouping, total soil thickness, porosity and physical and chemical parameters of each layer of soil. These parameters are given by DM Banner Soil and the physical and chemical parameters' investigation results of typical soil profile.

\section{Vegetation Database}

The vegetation map reflects the types of vegetation, the formation and sub-formation of vegetation, the conditions of horizontal zonal features and vertical zonal features. This study classified the vegetation in the study area according to the national land utilization classification system and built a vegetation database, as shown in Figure 4. The vegetation map and the attribute data in the vegetation database were connected through the lookup table (luc.txt) of the land utilization data. The physiological parameters of the vegetation are mostly determined through actual surveying, and given the actual conditions, the measured types of vegetation were compared and matched with the configured types of vegetation in the database of the model so that the types of vegetation in the study area were converted to the configured types in the model. The respective physiological parameters were revised according to actual conditions.

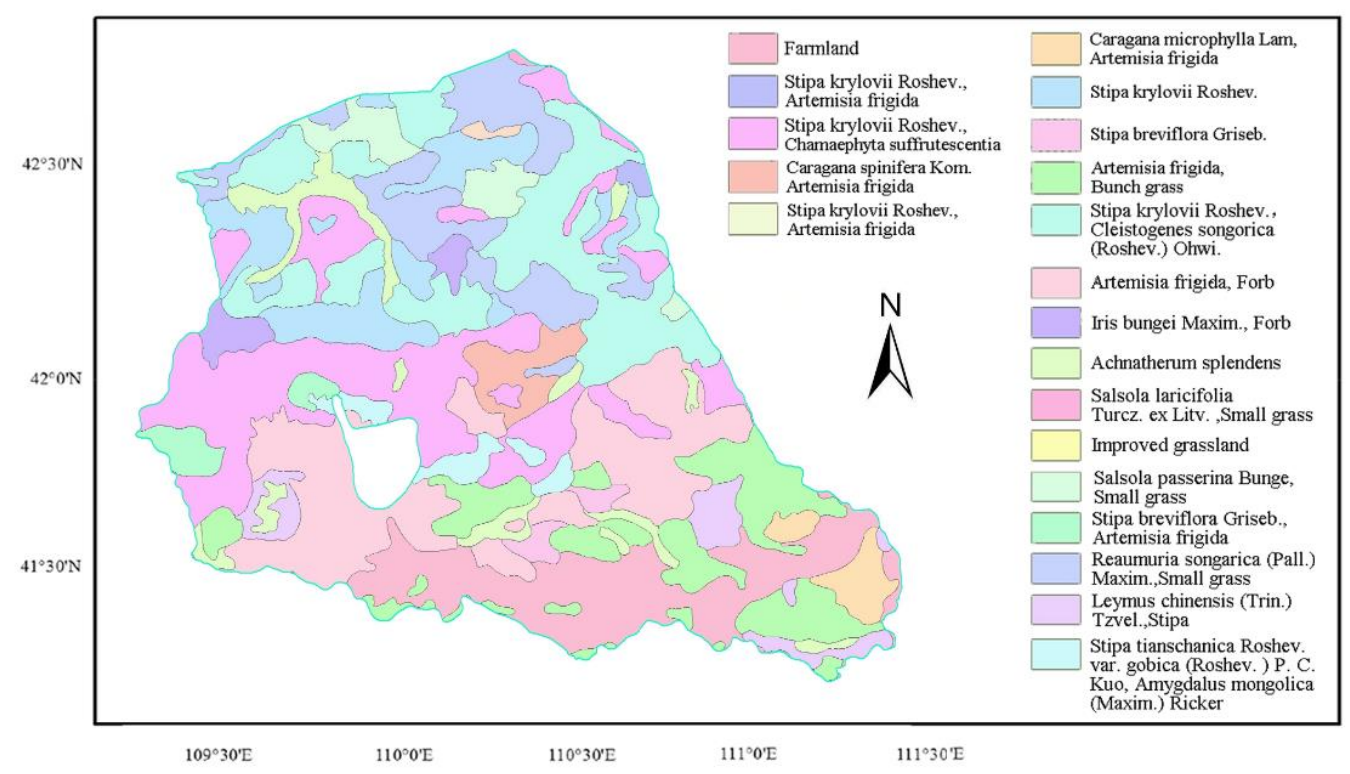

Figure 4. Vegetation Map of DM Banner

\section{Hydrological Data}

There was only one monitoring section in the study area, so a control node was set at the Bailinmiao Hydrologic Station to be used as runoff control and check section. The time scale was from 1975 to 1996. There are seven artificial reservoirs in the research area, as shown in Figure 5. Among them, the total reservoir capacity of Huanghua Beach reservoir, which is of medium and large size, accounts for $45.3 \%$ of the total reservoir capacity. And the total reservoir capacity of Yangyoufang reservoir accounts for $25.7 \%$ of the total reservoir capacity. The total storage capacity of the above two 
reservoirs accounts for $71 \%$ of the total storage capacity of the region. So the paper selects the above two reservoirs as a representative. In model, all of above two reservoirs' operation parameters, such as normal water level and its corresponding storage capacity, flood discharge level and corresponding storage capacity, hydraulic permeability coefficient of reservoir bottom, the year when the reservoir began to operate, the water storage way and drainage way, are input database. The water consumption data in the study area were obtained from statistical data and visits and surveys of relevant industry departments. According to the above data, the average annual total water consumption of each department in the region was $50,797,000 \mathrm{~m}^{3}$, which was mainly obtained from surface water and groundwater, and the total displacement is $6,688,800 \mathrm{~m}^{3}$, including $721,100 \mathrm{~m}^{3}$ for irrigation regression recharge of groundwater, $4,879,800 \mathrm{~m}^{3}$ for industry, $568,000 \mathrm{~m}^{3}$ for tertiary production, $520,000 \mathrm{~m}^{3}$ for urban residents living.

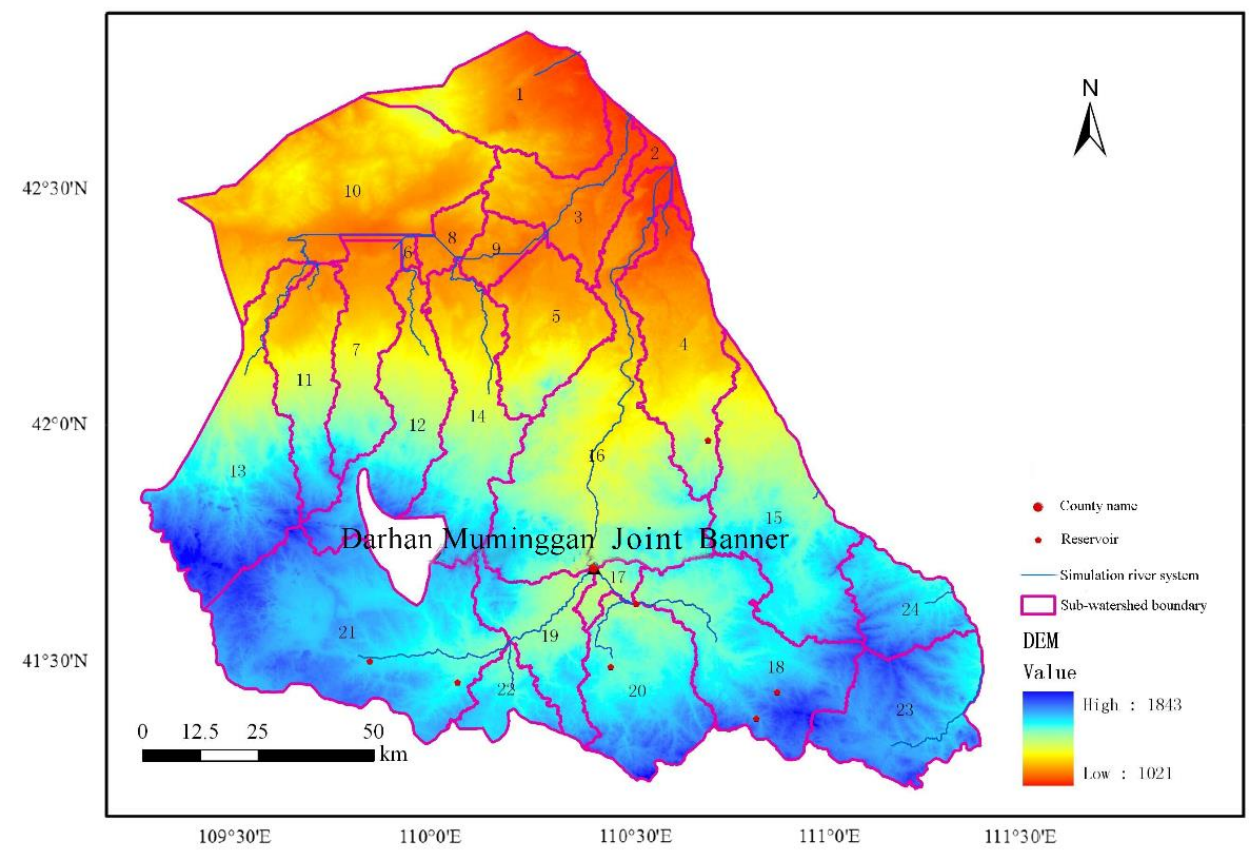

Figure 5. Drainage System and Sub-Catchments

The multi-year average water resources utilization and excretion data were modeled. Identifiable file by the model, which is composed of the position of intake and discharge ports, monthly water discharge and monthly water displacement, is input into the model.

\section{Modelling and Result Analysis}

\section{Sub-Catchment and Division of Hydrological Response Unit (HRU)}

On the distributed hydrological ArcSWAT model platform and according to the preset threshold of accumulated flow of $100 \mathrm{~km}^{2}$, the study area was distributed into 24 sub-catchments, as shown in Figure 5. The hydrological response unit consisted of three layers of data including the types of vegetation, the types of soil and the types of slopes. The types of vegetation were defined according to the vegetation map and the vegetation classification link; the types of soil was defined according to the soil map 
and the soil link; as there are no large gradients of slopes in the study area, there types of slopes were defined: slopes with a gradient between 0 and $15^{\circ}$, slopes with a gradient between $15^{\circ}$ and $30^{\circ}$, and slopes with a gradient of $30^{\circ}$. The hydrological response units were divided according to the percentage of data on each layer. We assume that when the rate of vegetation coverage in a region exceeds $15 \%$, the area of a type of soil exceeds $15 \%$ and the area of a type of slope exceeds $15 \%$, it forms a hydrological response unit. Each sub-catchment has multiple HRUs and there are $70 \mathrm{HRUs}$ in the study area.

\section{Model Calibration and Validation}

Given that the underlying surface conditions including vegetation coverage and soil in the 1980s and the 1990s are distinct from those in the 1950s and 1960s due to rapid development, and one hydrological cycle was included during the calibration period, the years from 1975 to 1985 are selected as the period for calibration of model parameters, and the years from 1987 to 1996 are selected as the period for model validation. The SWAT model uses the Nash-Sutcliffe model efficiency coefficient (NSE), the relative coefficient $\left(\mathrm{R}^{2}\right)$ and the relative error $(\mathrm{RE})$ to analyze the modelling accuracy to identify the modelling accuracy during the calibration period and the validation period at Bailingmiao Town Hydrological Station. On the yearly scale, the NSE during the model calibration period was 0.88 , the relative coefficient was 0.91 and the average error over years was 5\%; during the model validation period, the NSE was 0.41 , the relative coefficient was 0.42 and the average error over years was $-7 \%$, as shown in Table 2. The results of modelling accuracy during the model calibration period and the model validation period on the yearly scale are shown in Figure 6 and Figure 7.

Table 2. Simulation Effect of Yearly Scale Runoff by SWAT Model

\begin{tabular}{c|c|c|c|c|c|c}
\hline Period of time & Year & $\begin{array}{c}\text { Runoff } \\
\left(\mathbf{m}^{\mathbf{3}} / \mathbf{s}\right)\end{array}$ & $\begin{array}{c}\text { Simulated runoff } \\
\left(\mathbf{m}^{\mathbf{3} / \mathbf{s}}\right)\end{array}$ & $\mathbf{N S E}$ & $\mathbf{R E}$ & $\mathbf{R}^{\mathbf{2}}$ \\
\hline Calibration period & 1975 & 0.19 & 0.18 & 0.88 & $5 \%$ & 0.91 \\
& 1976 & 0.50 & 0.49 & & & \\
& 1977 & 0.42 & 0.31 & & & \\
& 1978 & 0.10 & 0.09 & & & \\
& 1979 & 0.70 & 0.68 & & & \\
& 1980 & 0.25 & 0.21 & & & \\
& 1981 & 0.99 & 1.14 & & & \\
& 1982 & 0.12 & 0.12 & & & \\
& 1983 & 0.21 & 0.36 & & & \\
& 1984 & 0.37 & 0.22 & & \\
Validation period & 1985 & 0.24 & 0.31 & & \\
& 1987 & 0.089 & 0.22 & 0.41 & $-7 \%$ & \\
& 1988 & 0.55 & 0.27 & & & \\
& 1989 & 0.25 & 0.22 & & & \\
& 1990 & 0.34 & 0.35 & & & \\
& 1991 & 0.084 & 0.13 & & & \\
& 1992 & 0.25 & 0.41 & & & \\
& 1993 & 0.12 & 0.2 & & & \\
& 1994 & 0.4 & 0.42 & & & \\
& 1995 & 0.42 & 0.4 & & & \\
& 1996 & 0.13 & 0.21 & & & \\
\hline
\end{tabular}



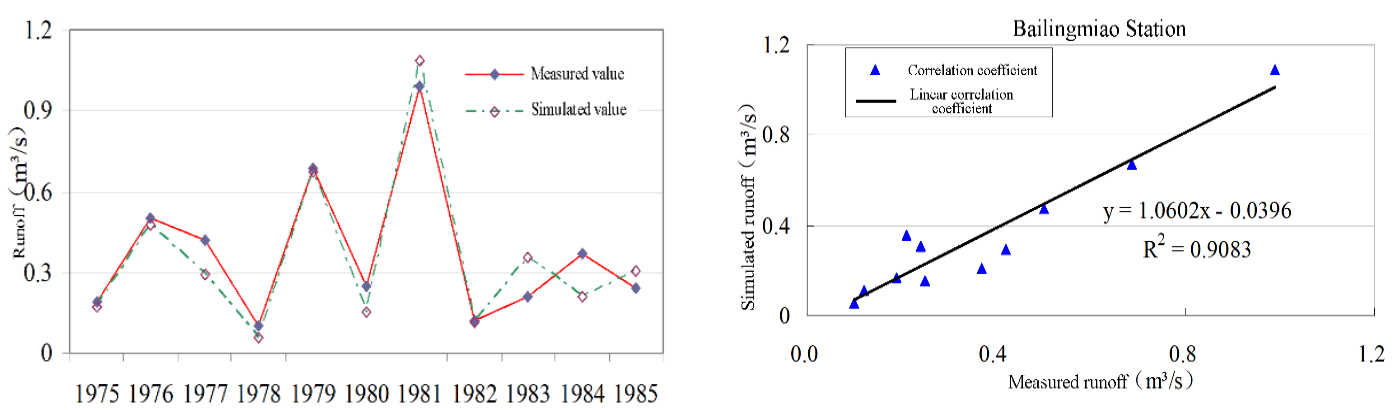

Figure 6. Accuracy during Calibration Period on yearly scale
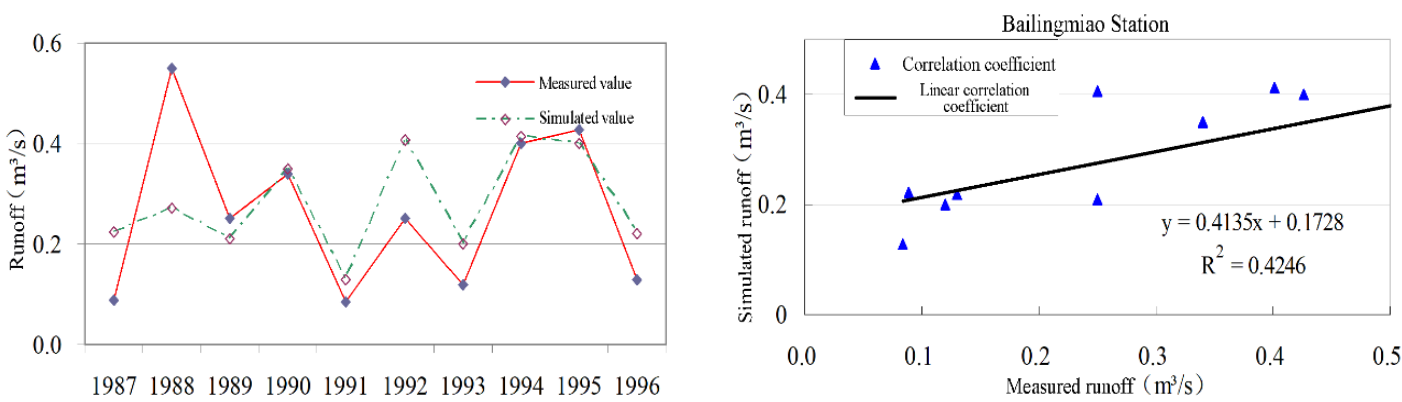

Figure 7. Accuracy during Validation Period on yearly scale

On the monthly scale, the NSE of Bailingmiao Town Hydrological Station during the calibration period was 0.70 , the relative coefficient was 0.70 and the average relative error over years was $7 \%$; during the validation period, the NSE was 0.47 , the relative coefficient was 0.57 and the average relative error over years was $26 \%$. Due to the large number of monthly scale data series, it is not detailed here, and the coefficients are shown in Table 3. On the monthly scale, the accuracy during the calibration period was shown in Figure 8 and Figure 9, and that during the validation period was shown in Figure 10 and Figure 11.

Table 3. Simulation Effect of Monthly Scale Runoff by SWAT Model

\begin{tabular}{c|c|c|c|c}
\hline Period of time & Year & NSE & RE & R2 \\
\hline Calibration period & $1975-1985$ & 0.70 & $7 \%$ & 0.70 \\
Validation period & $1987-1996$ & 0.47 & $26 \%$ & 0.57 \\
\hline
\end{tabular}

The total water yield of the basin (WYLD) equals the sum of surface runoff (SURQ), lateral runoff (LATQ) and underground runoff (GWQ) subtracting the runoff losses (TLOSS) and the amount of water left in reservoirs and lakes(pond). The equation is as shown below:

$$
W Y L D=S U R Q+L A T Q+G W Q-T L O S S-\text { pond }
$$

where, TLOSS can be neglected. 


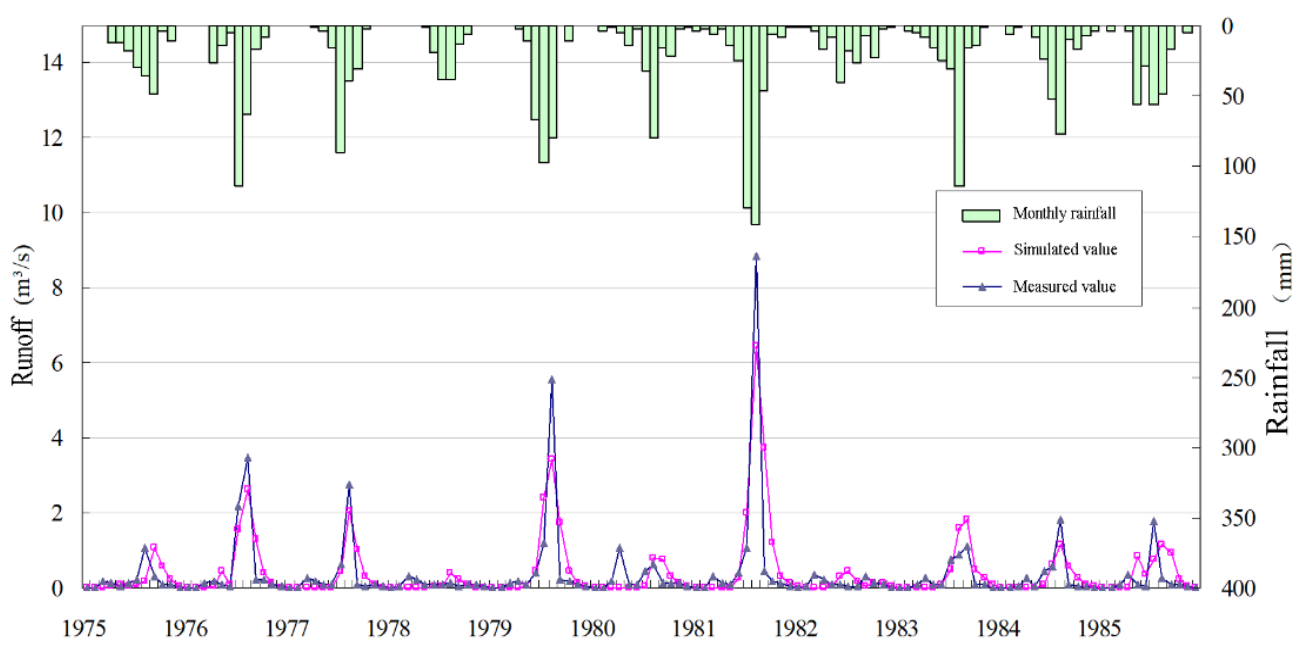

Figure 8. Accuracy during Calibration Period on Monthly Scale

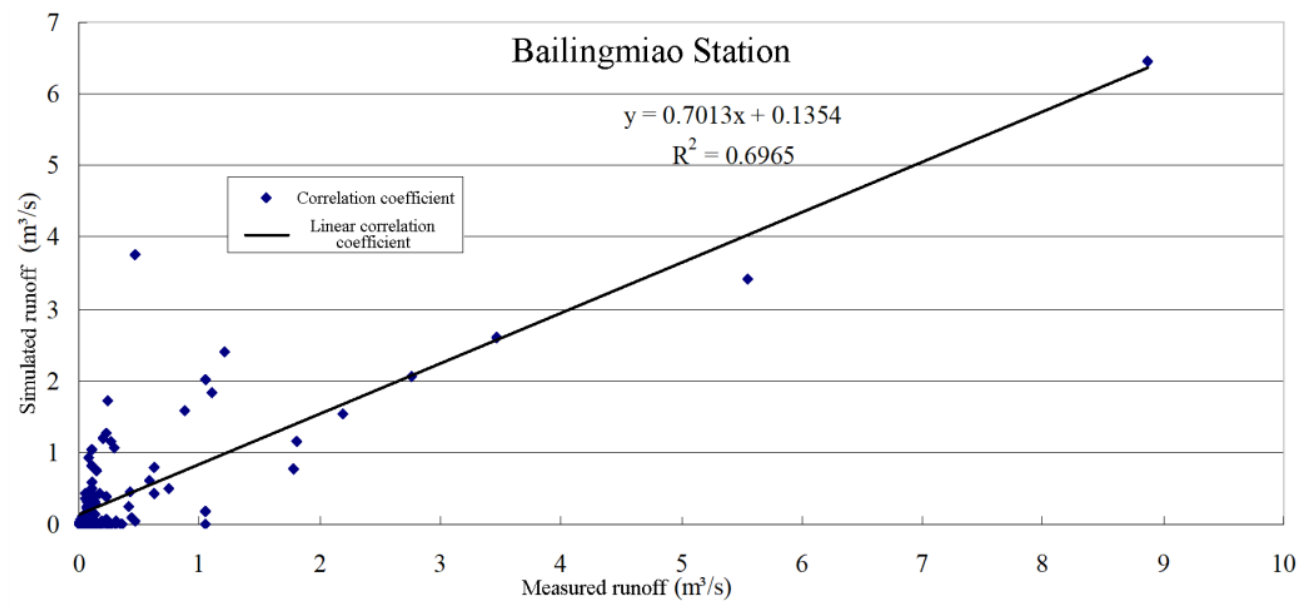

Figure 9. Correlation between Measured Runoff and Simulated Runoff during Calibration Period on Monthly Scale

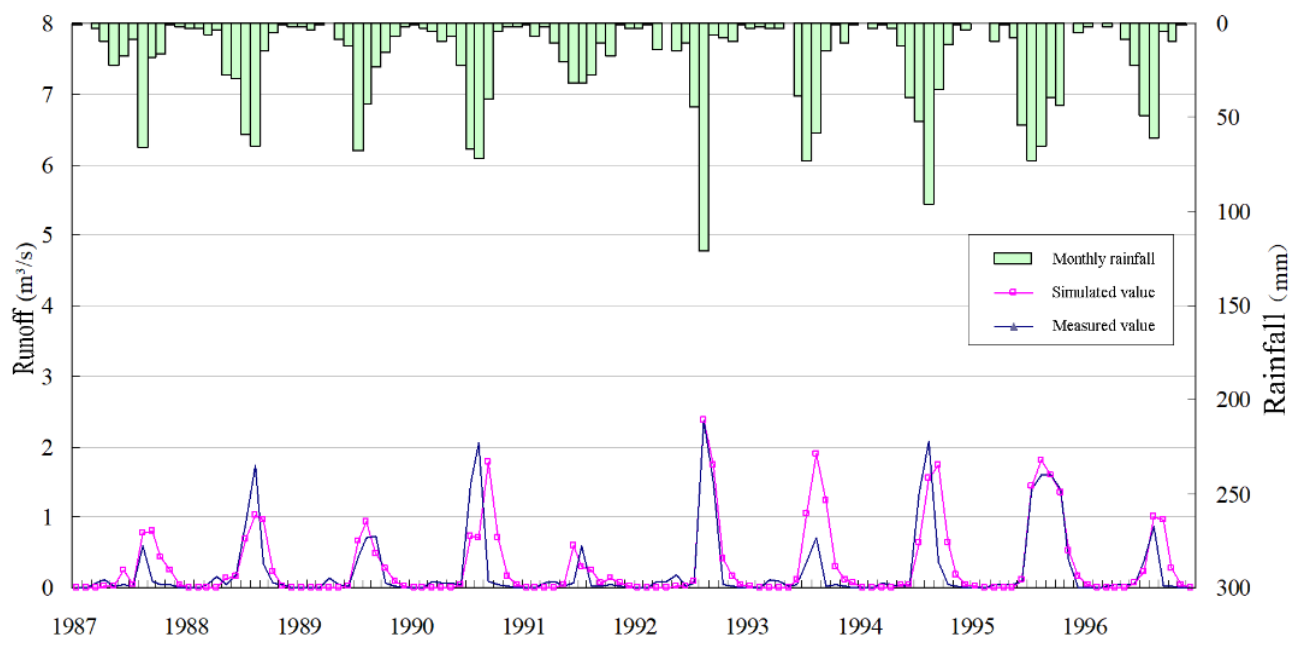

Figure 10. Accuracy during Validation Period on Monthly Scale 


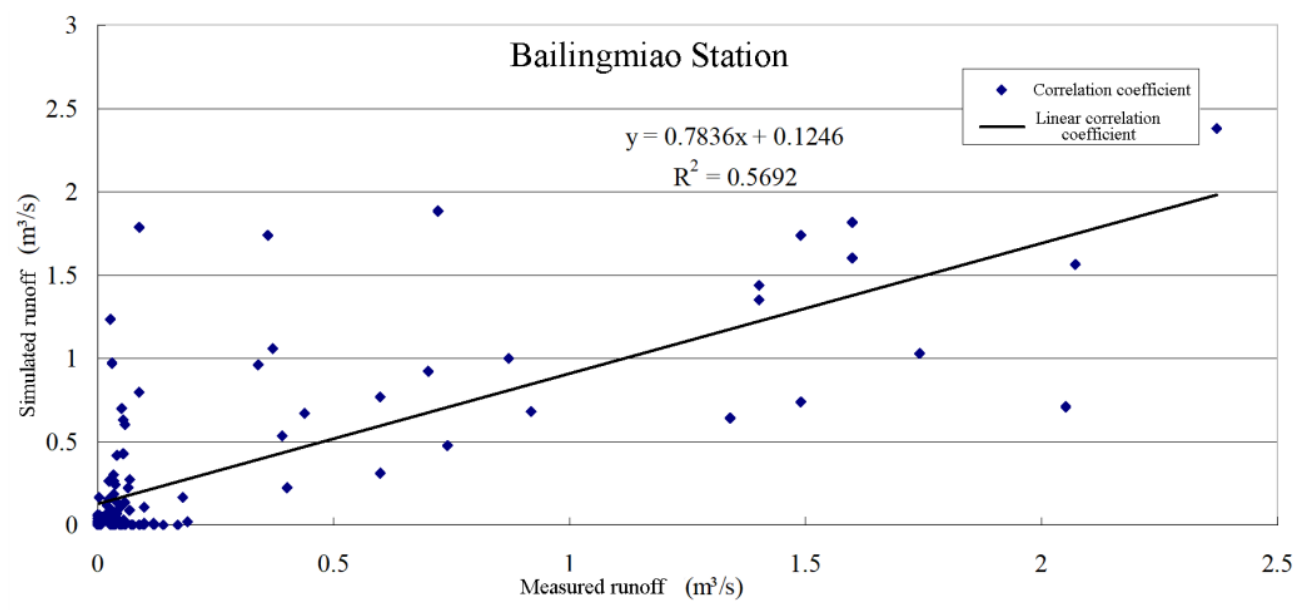

Figure 11. Correlation between Measured Runoff and Simulated Runoff during Validation Period on Monthly Scale

After verification with the data rate model parameters from 1975 to 1985 and the data from 1987 to 1996, the Nash coefficient and correlation coefficient were reasonable and the model parameters were reliable, the model could be used to predict the runoff changes under the changes of temperature and precipitation in the future.

\section{Future Scenario Prediction}

As the impact of the global and regional climate on forecast of climate changes in a small region is uncertain, this study defines the basic land use scenarios based on analysis of the trend of changes in meteorological factors and vegetation in the study area, and conducted quantitative modelling with calibrated model parameters to explore the impact of environmental changes on the water resources in the study area.

\section{Climate Change}

Since the end of 1980s, especially after 1995, the annual average temperature in the study area has been in the peak region, and the trend of temperature rising is very obvious, as shown in Figure 12.

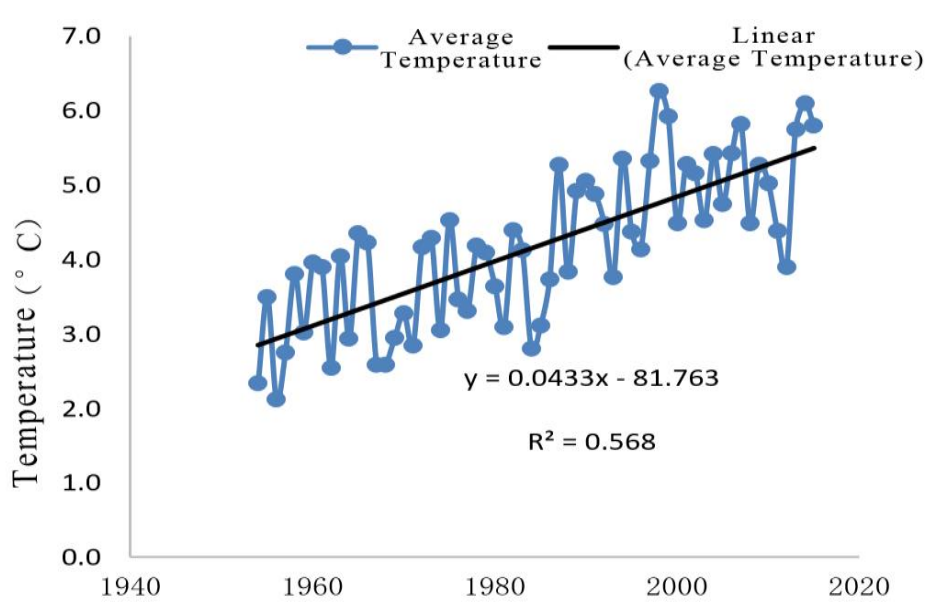

Figure 12. Trend of Annual Average Temperature 
The annual distribution of precipitation in the study area was extremely uneven, and the precipitation presented a wet - dry - wet - dry periodic change, as shown in Figure 13.

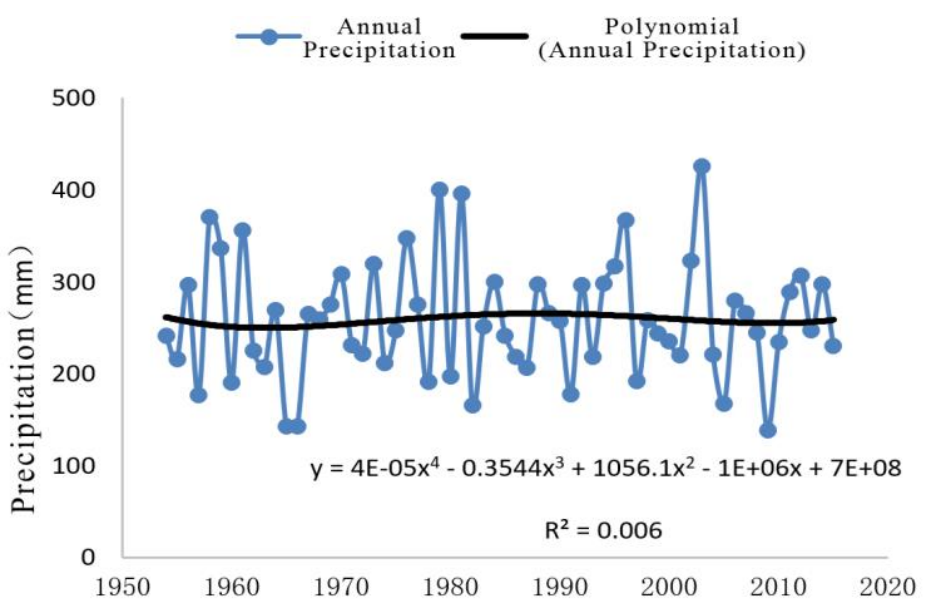

Figure 13. Trend of Annual Precipitation

\section{Vegetation Changes}

From 2000 to 2010, NDVI in DM Banner showed an overall trend of decrease. For many years, the maximum mean value of NDVI was 0.32, which appeared in 2004 and the minimum mean value of NDVI was 0.19, which appeared in 2009. From the above, difference degree of fluctuation was strong and there was no obvious linear relationship. It indicated that the anti-interference ability of desert steppe was poor, and the grassland showed a trend of degradation. The analysis of the relationship between the vegetation and the interannual variation of climate factors showed that temperature had positive and negative effects on the growth and development of herbage. The positive effects were mainly manifested in high temperature and good thermal conditions, which were conducive to the growth of herbage, but also the negative effects were caused by the increase of evapotranspiration consumption. And it could be showed that there was a significant positive correlation between precipitation and NDVI, with a correlation coefficient of 0.89 and increased precipitation is conducive to the growth of grass. The annual fluctuation of vegetation in DM Banner desert steppe was mainly controlled by the water condition, but the temperature was also an important factor, especially the minimum temperature (Hao et al., 2014).

\section{Future Scenario Setting}

As the result of analysis shows, the temperature in the study area increased, the precipitation showed cyclic changes, the area of surface vegetation was positively correlated to precipitation but showed no clear correlation to the temperature. Therefore, the following four future scenarios were set.

- Scenario 1: when the temperature rises $1^{\circ} \mathrm{C}$ and the precipitation reduces by $10 \%$, the rate of surface vegetation coverage drops by $10 \%$.

- Scenario 2: when the temperature rises $1^{\circ} \mathrm{C}$ and the precipitation increases by $10 \%$, the rate of surface vegetation coverage increases by $10 \%$. 
- Scenario 3: when the temperature rises $2^{\circ} \mathrm{C}$ and the precipitation reduces by $10 \%$, the rate of surface vegetation coverage drops by $10 \%$.

- Scenario 4: when the temperature rises $2^{\circ} \mathrm{C}$ and the precipitation increases by $10 \%$, the rate of surface vegetation coverage increases by $10 \%$.

\section{Results}

Table 4 shows the simulation result of changes in temporal and spatial distribution of water resources in four future scenarios, and the water yield in the study area in different scenarios was achieved. In Scenario 1, the water yield is $3.53 \mathrm{~mm}$, equivalent to 64.16 million $\mathrm{m}^{3}$ of water; In Scenario 2, the water yield is $5.68 \mathrm{~mm}$, equivalent to 103.25 million $\mathrm{m}^{3}$ of water; In Scenario 3, the water yield is $3.64 \mathrm{~mm}$, equivalent to 66.16 million $\mathrm{m}^{3}$; In Scenario 4, the water yield is $5.77 \mathrm{~mm}$, equivalent to 104.88 million $\mathrm{m}^{3}$. As the model requires input of lots of data, only the basic parameters available were input into the model in this study. In particular, the pastures in China are large and rivers abound in grasslands, but there are few hydrological stations which can produce only short-series data. Insufficient data may to some extent influence the accuracy of parameter model calibration and validation.

Table 4. Forecast of Water Resources in Different Scenarios

\begin{tabular}{c|c|c|c|c|c|c|c|c}
\hline Scenario & $\begin{array}{c}\text { Precipi- } \\
\text { tation }\end{array}$ & $\begin{array}{c}\text { Surface } \\
\text { runoff }\end{array}$ & $\begin{array}{c}\text { Underground } \\
\text { runoff }\end{array}$ & $\begin{array}{c}\text { Soil } \\
\text { water } \\
\text { content }\end{array}$ & $\begin{array}{c}\text { Evapo- } \\
\text { ration }\end{array}$ & $\begin{array}{c}\text { Potential } \\
\text { evaporation }\end{array}$ & $\begin{array}{c}\text { Water } \\
\text { yield }\end{array}$ & $\begin{array}{c}\text { Measured } \\
\text { Water } \\
\text { yield }\end{array}$ \\
\hline 1 & 211.74 & 3.53 & 9.3 & 0.45 & 198.87 & 956.95 & 3.53 & \\
2 & 258.79 & 5.68 & 25.66 & 0.62 & 227.49 & 956.49 & 5.68 & 3.06 \\
3 & 211.74 & 3.64 & 8.68 & 0.45 & 199.2 & 996.43 & 3.64 & \\
4 & 258.79 & 5.77 & 24.39 & 0.64 & 228.44 & 996.07 & 5.77 & \\
\hline
\end{tabular}

Unit: $\mathrm{mm}$

\section{Discussion}

Because of the lack of water resources and the fragile ecological environment in arid pastoral area of China, grassland ecological animal husbandry and regional economic and social development are mainly restricted by water resources. Reasonable and efficient use of limited water resources is the importance premise for the implementation of the corresponding industry development policy. And the ultimate goal is to achieve economic and social development of pastoral areas and grassland ecological protection win-win. So prediction of water resources in arid pastoral areas under future environmental changes is the basis of efficient utilization of local water resources.

In this paper, SWAT model was established in the study area to simulate and predict the change of local future runoff, so as to provide a scientific basis for the optimal allocation and management of region water resources in the future. Although the model input data required more, by the limit of the natural conditions of China's vast pastoral areas and numerous grasslands river, the study only collected the most basic input parameters for model. Now the number of corresponding hydrological stations is very small, and the data series is relatively short. Inadequate data input as mentioned above 
for parameter calibration and simulation accuracy may cause a certain influence. We have set up another long-term meteorological observatory in the Xilamuren Town of DM Banner. It's just that the monitoring time is short and it's not fully working. But we will continue to collect new meteorological and hydrological data in the future, in order to improve the model that we established and improve the accuracy of the model. This is a better support for sustainable use of water resources to support sustainable economic and social development in arid pastoral areas.

Acknowledgements. This study is supported by Natural Science Foundation of Inner Mongolia Autonomous Region of China (2017MS0516), National Natural Science Foundation of China (51009098), Special Fund of State Key Laboratory of Simulation and Regulation of Water Cycle in River Basin, China Institute of Water Resources and Hydropower Research (Grant NO. SKL2018ZY01), Xinjiang Science and Technology Support Project (201531115), and the Special Funds for Public Welfare Research of Ministry of Water Resources (201201008). Thanks are extended to the reviewers for their constructive comments.

\section{REFERENCES}

[1] Bannwarth, M. A., Sangchan, W., Hugenschmidt, C., Lamers, M., Ingwersen, J., Ziegler, A. D., Streck, T. (2014): Pesticide transport simulation in a tropical catchment by SWAT. - Enviromental Pollution 191: 70-79.

[2] Chen, Z. W., Liu, X. N., Zhu, B. (2014): Runoff estimation in hillslope cropland of purple soil based on SCS-CN model. - Transactions of the Chinese Society of Agricultural Engineering 30(7): 72-81.

[3] Cheng, L., Xu, Z. X., Luo, R., Mi, Y. J. (2009): SWAT application in arid and semi-arid region: A case study in the Kuye River Basin. - Geographical Research 28(01): 65-73.

[4] Duan, C. Y., Zhang, S., Li, J. R., Zhang, C. F., Qi, J. Y., Wu, Y. (2014): Analysis on Rainfall- Runoff Characteristics and Simulation of the Different Hydrologic Year Runoff of Xilin River Basin in Inner Mongolia Based on SWAT Model. - Research of Soil and Water Conservation 21(05): 292-297+341.

[5] El-Khoury, A., Seidou, O., Lapen, D. R., Que, Z., Mohammadian, M., Sunohara, M., Bahram, D. (2015): Combined impacts of future climate and land ues changes on discharge, nitrogen and phosphorus loads for a Canadian river basin. - Journal of Environmental Management 151: 76-86.

[6] Guo, J. T., Zhang, Z. Q., Wang, S. P., Strauss, P., Yao, A. (2014): Appling SWAT model to explore the impact of changes in land use and climate on the streamflow in a Watershed of Northern China. - Acta Ecologica Sinica 34(06): 1559-1567.

[7] Hao, W. G., Li, J. R., Guo, J. Y., Shen, J., Zhang, S. (2014): Dynamic changes of vegetation in desert grassland and precipitation and temperature responses. - Water Resources Protection 30(05): 56-59.

[8] Hoang, L., Griensven, A. V., Mynett, A. (2017): Enhancing the SWAT model for simulating denitrification in riparian zones at the river basin scale. - Environmental Modelling \& Software 93: 163-179.

[9] Huang, Q. H., Zhang, W. C. (2010): Application and parameters sensitivity analysis of SWAT model. - Arid Land Geography 33(1): 8-15.

[10] Lai, Z. Q., Li, S., Li, C. G., Nan, Z. T., Yu, W. J. (2013): Improvement and Applications of SWAT Model in the Upper-middle Heihe River Basin. - Journal of Natural Resources 28(08): 1404-1413.

[11] Li, S., Lai, Z. Q., Wang, Q., Wang, Z. H., Li, C. G., Song, X. B. (2013): Distributed simulation for hydrological process in Plain River network region using SWAT model. Transactions of the Chinese Society of Agricultural Engineering 29(6): 106-112. 
[12] Li, D. H., Wang, J. Y., Wang, S. G., Li, Z. C., Shang, K. Z., Shi, J. S. (2014): Change Features of Surface Albedo of Semi-Arid Grassland over the Loess Plateau of Middle Part Gansu. - Plateau Meteorology 33(01): 89-96.

[13] Manoj, K. S., Friedrich, R. (2016): Assessing SWAT models based on single and multisite calibration for the simulation of flow and nutrient loads in the semi-arid Onkaparinga catchment in South Australia. - Agricultural Water Management 175: 61-71.

[14] Meng, X. Y., Ji, X. N., Liu, Z. H., Xiao, J. C., Chen, X., Wang, F. (2014): Research on Improvement and Application of Snowmelt Module in SWAT. - Journal of Natural Resources 29(03): 528-539.

[15] Wang, Z. G., Liu, C. M., Huang, Y. B. (2003): The Theory of SWAT Model and its Application in Heihe Basin. - Progress in Geography 22(1): 79-86.

[16] Wang, X. Y., Qin, F. L., Ou, Y., Xue, Y. F. (2008): SWAT- Based Simulation on Nonpoint Source Pollution in the Northern Watershed of Miyun Reservoir. - Journal of AgroEnvironment Science 27(3): 1098-1105.

[17] Wei, C., Song, X., Chen, J. (2014): Sensitivity analysis of swat model on changes of landscape pattern:a case study from Lao Guanhe Watershed in Danjiangkou Reservoir Area. - Acta Ecologica Sinica 34(02): 517-525.

[18] Yu, W. J., Nan, Z. T., Zhao, Y. B., Li, S. (2013): Improvement of snowmelt implementation in the SWAT hydrologic model. - Acta Ecologica Sinica 33(21): 69927001.

[19] Yuan, Y. Z., Zhang, Z. D., Meng, J. H. (2015): Impact of changes in land use and climate on the runoff in Liuxihe Watershed based on SWAT model. - Chinese Journal of Applied Ecology 26(04): 989-998.

[20] Zhang, X. S., Hao, F. H., Yang, Z. F., Cheng, H. G., Li, D. F. (2003): Runoff and Sediment Yield Modeling in Meso-scale Watershed Based on SWAT Model. - Research of Soil and Water Conservation 10(4): 38-42.

[21] Zhang, D., Zhang, W. C., Zhu, L., Zhu, Q. (2005): Improvement and Application of SWAT-A Physically Based, Distributed Hydrological Model. - Scientia Geographica Sinica 25(4): 434-440.

[22] Zhao, A. Z., Liu, X. F., Zhu, X. F., Pan, Y. Z., Li, Y. Z. (2015): Spatiotemporal patterns of droughts based on SWAT model for the Weihe River Basin. - Progress in Geography 34(09): 1156-1166. 